\title{
Pengaruh Mendongeng Terhadap Keterampilan Menyimak Pada Anak Usia 5 -6 Tahun di TK Ibnu AL - Akbar Kecamatan Beringin Kabupaten Deli Serdang
}

Received : 10 Maret 2020

Revised : 20 Mei 2020

Accepted : 2 Juni 2020

\author{
Fanny Octivasari ${ }^{1}$, Nasriah $^{2}$ \\ Fakultas Ilmu Pendidikan \\ Universitas Negeri Medan \\ Jln. Willem Iskandar Psr V Medan Estate \\ E-mail : octivasarifanny@gmail.com
}

\begin{abstract}
Abstrak. Permasalahan dalam penelitian ini adalah : minimnya kegiatan-kegiatan di dalam kelas yang mengembangkan keterampilan menyimak pada anak. Penelitian ini bertujuan untuk mengetahui pengaruh mendongeng terhadap keterampilan menyimak anak usia 5-6 tahun di TK IBNU AL-AKBAR Kec. Beringin Kab. Deli serdang Tahun Ajaran 2015/2016. Jenis penelitian ini adalah penelitian post test only control design. Populasi dalam penelitian dilakukan dengan menggunakan dua kelas kelompok yang memiliki karakteristik yang sama yaitu seluruh B1 dan B2 yang berjumlah 40 orang. Penentuan sampel kelas dilakukan secara acak ( random )dengan jumlah sampel setiap kelas masing-masing sebanyak 20 anak. Instrumen pengumpulan data dalam penelitian ini adalah pedoman obesrvasi. Dan penggunaan analisis data menggunakan uji-t. Pada saat mengobservasi, pengobservasi menggunakan pedoman observasi yang telah ditentukan yaitu taraf nyata $\alpha=0,05$
\end{abstract}

\begin{abstract}
Berdasarkan hasil observasi keterampilan menyimak anak dikelas eksperimen memiliki nilai rata-rata 39,5 dengan nilai tertinggi 48 dan nilai terendah 25, sehingga keterampilan menyimak pada anak dengan mendongeng pada kelas eksperimen memperoleh perbedaan yang signifikan. Sedangkan nilai hasil observasi keterampilan menyimak anak dikelas kontrol yang memiliki rata-rata 24,45 dengan nilai tertinggi 35 dan nilai terendah 15 , sehingga keterampilan menyimak pada anak dengan mendongeng pada kelas kontrol memperoleh perbedaan yang signifikan. Berdasarkan hasil tersebut, hipotesis menyatakanbahwa pembelajaran menggunakan metode mendongeng anak berpengaruh secara signifikan terhadap perkembangan keterampilan menyimakanak yaitu dari hasil hipotesis diperoleh thitung $>$ ttabel yaitu $9.336>1,707$ pada taraf $\alpha=0,05$.
\end{abstract}

Berdasarkan penjelasa yang telah dipaparkan dapat ditarik kesimpulan bahwa mendongeng memiliki pengaruh yang signifikan terhadap keterampilan menyimak pada anak dibanding dengan kelas kontrol yang menggunakan metode tanya jawab.

Kata Kunci: Mendonggeng, Keterampilan Menyimak

\section{PENDAHULUAN}

Menyimak adalah suatu proses kegiatan mendengarkan lambang-lambang lisan dengan penuh perhatian, pemahaman, apresiasi, interpretasi untuk memperoleh informasi, menangkap isi atau pesan serta memahami makna komunikasi yang telah disampaikan oleh pembicara melalui ujaran atau bahasa lain. Dari kegiatan menyimak diharapkan anak akan terlatih menjadi penyimak yang kreatif dan kritis. Pengembangan keterampilan menyimak pada anak usia dini memerlukan metode yang tepat, salah satunya adalah metode mendongeng, yang banyak dipergunakan di pendidikan anak usia dini. 
Metode mendongeng merupakan salah satu strategi pembelajaran yang dapat memberikan pengalaman belajar bagi anak usia dini. Dongeng yang dibawakan guru secara lisan harus menarik, dan mengundang perhatian anak dan tidak lepas dari tujuan pendidikan anak usia dini (Masitoh, 2006: 3-10). Apabila isi dongeng dikaitkan dengan dunia kehidupan anak, mereka akan mendengarkannya dengan penuh perhatian dan dapat menangkap isi cerita dongeng dengan mudah. Di samping itu dapat menciptakan suasana yang menyenangkan, bercerita dapat mengundang dan merangsang proses kognisi, khusus aktivitas berimajinasi, dapat menjadi sarana untuk belajar, serta dapat berfungsi untuk membangun hubungan yang akrab.

Berdasarkan pengamatan awal yang dilakukan peneliti di TK IBNU AL-AKBAR, masih ditemukan bahwa sebagian besar anak didik kurang memiliki keterampilan menyimak. Hal ini ditunjukkan dengan sebanyak 11 anak dari total 20 anak belum muncul indikator keterampilan menyimak, seperti mendengarkan penuh perhatian, mengiterpretasikan cerita dan memahami makna. Sebagaimana juga dinyatakan oleh kepala sekolah dan beberapa guru pengajar, bahwa rendahnya keterampilan menyimak anak didik terlihat dari komunikasi yang mereka gunakan sehari-hari di sekolah, kadang juga ada anak yang tidak mau menjawab jika ada pertanyaan dari guru atau dalam kegiatan lain. Selain itu, metode mendongeng belum digunakan sesuai dengan penerapan teknik-teknik mendongeng dalam meningkatkan keterampilan menyimak pada anak.

Dengan melihat pentingnya kegiatan mendongeng pada pembelajaran anak usia dini khususnya dalam mengembangkan keterampilan menyimak anak, maka peneliti berkeinginan melakukan penelitian dengan judul "Pengaruh Mendongeng Terhadap Keterampilan Menyimak Pada Anak Usia 5-6 Tahun Di TK IBNU AL-AKBAR Kec. Beringin Kab. Deliserdang Tahun Ajaran 2015/2016

\section{METODOLOGI PENELITIAN}

Metode penelitian yang digunakan dalam penelitian ini adalah metode penelitian eksperimen.Desain dalam penelitian ini adalah True EksperimentalDesign, dengan bentuk Postest-Only Control Design dalam model ini terdapat kelompok eksperimen dan kelompok Kontrol yang dipilih secara random. Sugiyono (2010:117) mengatakan populasi adalah wilayah generalisasi yang terdiri atas : objek/subjek yang mempunyai kualitas dan karakteristik tertentu yang ditetapkan peneliti untuk dipelajari dan kemudian ditarik kesimpulannya. Dari definisi diatas, maka populasi dalam penelitian ini adalah seluruh anak di TK B IBNU AL-AKBAR Tahun Ajaran 2015/2016. Adapun anak kelompok B di TK IBNU AL-AKBAR terdiri dari dua kelas yaitu B1 dan B2 dengan jumlah 40 orang.

Dalam penelitian ini teknik pengumpulan data yang digunakan adalah observasi. Metode observasi dilakukan dengan cara mengamati dan mencatat semua aktivitas anak pada proses kegiatan kolase di kelas. Observasi dilakukan pada anakkelompok Buntuk memperoleh data anak yang berkaitan dengan aspek-aspek kreativitas anak.Penyusunan data dilakukan dengan memuat namaanak.Tugas observer memberi tanda checklist $(\checkmark)$ pada skor yang di dapat melalui pedoman observasi yang dibuat. Dari hasil observasi yang dilakukan maka akan diperoleh data tentang keterampilan menyimak pada saat menerapkan metode mendongeng pada saat pembelajaran. 
Tabel. 1. Kisi-Kisi Lembar Observasi Keterampilan Menyimak

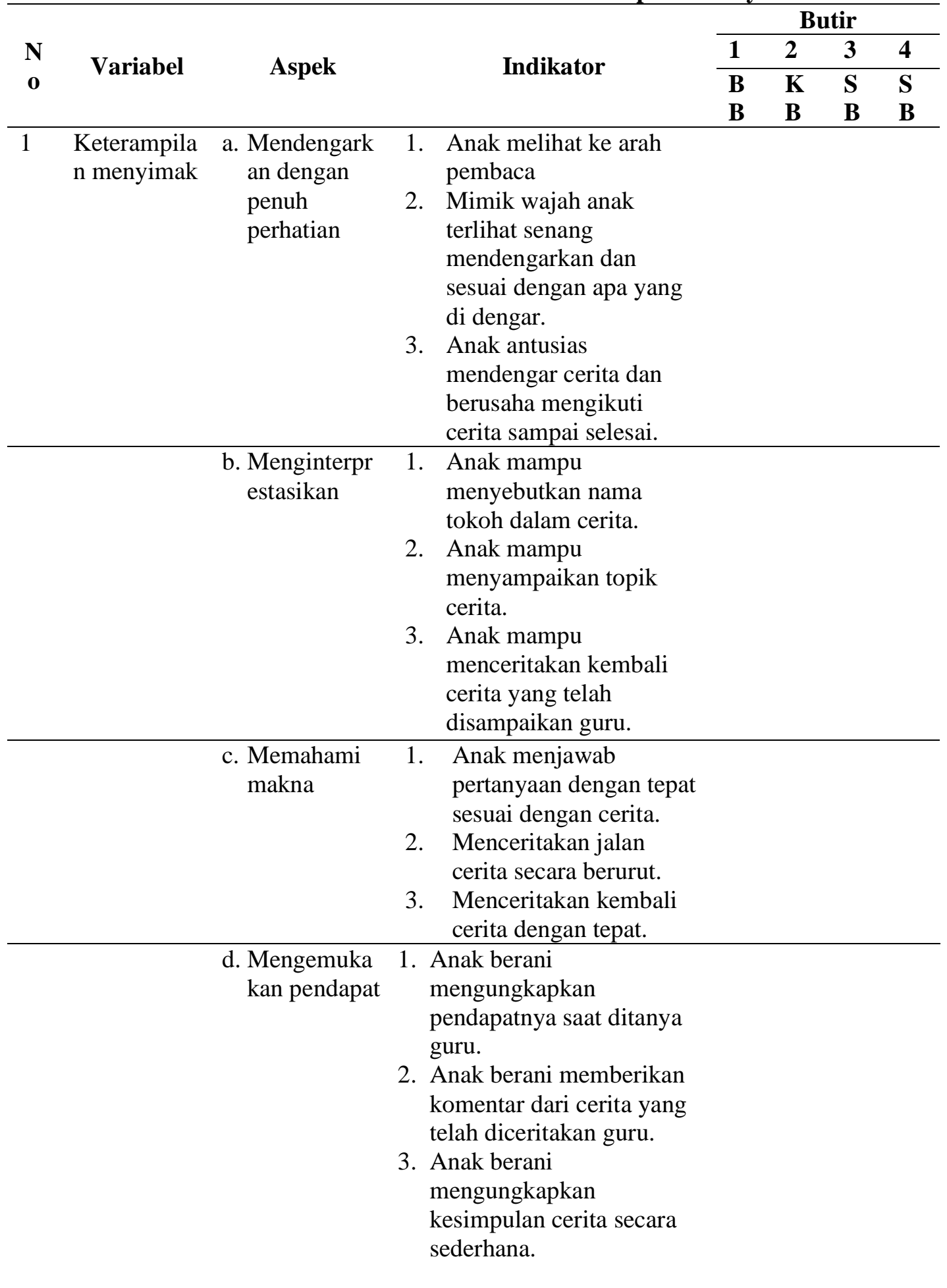


Petunjuk:

Untuk memberi skor pada butir-butir keterampilan menyimak anak maka centang $(\checkmark)$ angka pada kolom skor $(1,2,3,4)$ sesuai dengan kriteria berikut:

$1=\mathrm{BB}($ Belum Berkembang)

$2=\mathrm{KB}$ (Kurang Berkembang)

$3=\mathrm{SB}($ Sedang Berkembang)

$4=$ SB $($ Sudah Berkembang)

\section{HASIL DAN DISKUSI}

Telah diterangkan sebelumnya pada bab III bahwa dalam penelitian ini dikumpulkan dengan teknik observasi. Lembar observasi telah disusun sehingga dapat digunakan untuk melihat data perkembangan kreativitas anak.

Dari observasi, dapat dilihat bahwa dengan kegiatan membatik memberikan perbedaan pada perkembangan kreativitas anak di kelas kontrol dan kelas eksperimen. Perbedaan tersebut dapat dilihat dalam tabel dibawah ini

Tabel 2 Perbedaan Hasil Data Kelas Eksperimen dan Kelas Kontrol

\begin{tabular}{lccccc}
\hline & Kelas Ekperimen & \multicolumn{4}{c}{ Kelas Kontrol } \\
\hline No & Nilai Observasi Akhir & Frekuensi & No & Nilai Observasi Akhir & Frekuensi \\
\hline 1. & $45-48$ & 10 & 1. & $31-35$ & 2 \\
\hline 2. & $41-44$ & 0 & 2. & $27-30$ & 7 \\
\hline 3. & $37-40$ & 4 & 3. & $23-26$ & 4 \\
\hline 4. & $33-36$ & 2 & 4. & $19-22$ & 4 \\
\hline 5. & $29-32$ & 1 & 5. & $15-18$ & 3 \\
\hline 6. & $25-28$ & 3 & & $\mathbf{2 0}$ \\
\hline Jumlah & & $\mathbf{2 0}$ & Jumlah \\
\hline Rata-rata $=\mathbf{3 . 2 9}$ & \multicolumn{5}{l}{ Rata-rata $=\mathbf{2 4 . 4 5}$} \\
\hline
\end{tabular}

Berdasarkan data hasil observasi kelas eksperimen dan kelas kontrol diatas, maka dijelaskan bahwa anak kelas eksperimen memiliki nilai terendah, nilai tertinggi, nilai ratarata yang lebih tinggi dibandingkan kelas kontrol. Hal ini menunjukkan bahwa keterampilan menyimak anak kelas eksperimen lebih baik dibandingkan kelas kontrol, dimana perkembangan tersebut dipengaruhi oleh penggunaan metode mendongeng.

\section{PEMBAHASAN}

Berdasarkan hasil penelitian yang diperoleh yaitu untuk mengetahui keterampilan menyimak anak usia 5-6 tahun melalui metode mendongeng di TK IBNU AL-AKBAR, maka penelitian melakukan pengumpulan data dengan menggunakan pedoman observasi, sebelum melakukan observasi, terlebih dahulu pilih kelas yang akan diteliti dan dibagi menjadi kelas eksperimen yang akan diberi perlakuan dan kelas kontrol perlakuan yang berbeda.

Setelah dilakukan perlakuan yang berbeda diperoleh rata-rata skor keterampilan menyimak anak di kelas eksperimen 39,5 dan kelas kontrol 24,45. Dari hasil observasi kedua sampel tersebut diperoleh selisih 15,05 dari data yang diperoleh terdapat perbedaan 
yang signifikan antara keterampilan menyimak anak kelas eksperimen dan kelas kontrol. Hal ini disebabkan karena adanya penggunaan metode mendongeng yang dapat membuat anak usia 5-6 tahun lebih dapat menginterprestasikan cerita yang telah ia dengar hal ini di dukung dengan pendapat DS Agus (2008:136) yang mengatakan kegiatan mendongeng merupakan suatu cara untuk mengembangkan kemampuan menyimak anak dan melatih konsentrasi anak untuk lebih memperhatiakan dalam pembelajaran berlangsung. Hal ini terlihat dari lebih berkembangnya keterampilan menyimak anak pada kelas eksperimen dibandingkan dengan kelas kontrol.

Maka berdasarkan penelitian yang telah dilakukan di TK IBNU AL-AKBAR dapat disimpukan bahwa metode mendongeng memberi pengaruh yang positif terhadap keterampilan menyimak anak.

\section{SIMPULAN}

Berdasarkan hasil penelitian dan pengolahan data pada sub bab sebelumnya dapat di ambil kesimpulan, yaitu :

1. Hasil observasi keterampilan menyimak anak dikelas eksperimen memiliki nilai rata-rata 39,5 lebih besar dibandingkan dengan hasil observasi keterampilan menyimak anak dikelas kontrol yang memiliki rata-rata 24,45 dapat diartikan bahwa ada pengaruh mendongeng terhadap keterampilan menyimak anak. Selain dapat mengembangkan keterampilan menyimak anak dengan memberikan cerita dongeng makan anak dapaat mendengarkan dengan pusat perhatia, dan dapat menginterprestasikan apa yang telah anak dengar dan juga memahami makna apa yang telah anak dengarkan.

2. Hasil nilai uji hipotesis terbukti bahwa thitung $(9.336)>$ ttabel $(1,707)$. Hal tersebut sesuai dengan hasil uji hipotesis Ho ditolak dan Ha diterima, sehingga dapat dinyatakan ada pengaruh yang signifikan dari kegiatan mendongeng terhadap keterampilan menyimak anak usia 5-6 tahun di TK Ibnu Al-Akbar Kec. Beringin Kab. Deliserdang tahun ajaran 2015/2016.

Berdasarkan kesimpulan diatas, maka peneliti mengajukan beberapa saran yaitu :

1. Bagi guru dan calon guru diharapkan dapat menerapkan kegiatan mendongeng dalam pembelajaran untuk meningkatkan keterampilan menyimak anak.

2. Bagi peneliti selanjutnya yang ingin meneliti labih lanjut mengenai pembelajaran dengan kegiatan mendongeng untuk meningkatkan keterampilan menyimak anak agar lebih memperhatikan kelemahankelemahan dalam pembelajaran, sehingga dapat diperoleh hasil yang lebih baik pada peneliti selanjutnya.

3. Bagi kepala sekolah sebagai bahan pertimbangan untuk mengoptimalkan meningkatkan keterampilan menyimak anak

\section{DAFTAR RUJUKAN}

Abdul Latif Muhammad. (2014). Mendongeng Mudah Menyenangkan. Aplikasi Penerapan dalam Mendukung Pelajaran. Jakarta. Luxima.

Azies \& Alwasih. (2000). Pengajaran Bahasa Komunikatif. Bandung: Remaja Rosdakarya.

Bunanta Murti . 2008. Buku Mendongeng dan Minat Membaca. Jakarta. Ilmu Populer.

Baarnawi Novan dan Ardy Wiyani. (2012). Format PAUD. Jakarta: Ar-Ruzz. 
DS Agus. 2008. Mendongeng Bareng Agus DS Yuk. Yogyakarta. Kanisus.

Dhieni Nurbiana. (2007). Model Pengembangan Bahasa. Jakarta: Universitas Terbuka.

Fadhillah, Muhammad. 2012. Desaign Pembelajaran PAUD. Tinjaun Teoritik dan Praktik. Jogjakarta: Ar-ruzz Media.

Intan Kurnia Nandy. (2010). Pengembangan Kemampuan Menyimak bagi Ana-kanak Usia Muda dengan Memanfaatkan Teknologi Internet. Yogyakarta: PBI FBS UNY.

Istarani. 2012. Kumpulan 39 Metode Pembelajaran. Medan: ISCOM MEDAN. Kamijan dan Suyono. 2002. Pelatihan Terintegrasi Berbasis KompetensiPelajaran Menyimak. Jakarta : Depdiknas.

Kurniawan Henru. 2013. Keajaiban Mendongeng dan Minat Membaca. Jakarta. KPBA.

Majid Abdul, Aziz Abdul. (2002). Mendidik Dengan Cerita. Bandung Remaja Rosdakarya.

Majid Abdul (2009). Perencanaan pembelajaran. Bandung: Remaja Rosdakarya.

Masitoh. (2006). Pendekatan Pembelajaran TK. Jakarta: Universitas Terbuka.

Muh. Nur Mustakim. (2005). Peranan Cerita dalam Pembentukan Perkembangan Anak TK. Jakarta: Depdiknas.

Munandar S.C Utami. (2000). MengambangkanBakat dan Kreativitas Anak Sekolah Penuntun Bagi Orang Tua. Jakarta. Gramedia Widiasarana.

NurgiyantoroBurhan.2013. Sastra Anak.PengantarPemahaman Dunia Anak. Yogyakarta. Gajah Mada Universiti Press.

Peraturan Menteri Pendidikan Indonesia Nomor 058. (2009). Tentang Standart Pendidikan Anak Usia Dini. Jakarta: Permendiknas.

Panuti Sudjiman . (2013). Kamus Istilah Sastra. Jakarta: Universitas Indonesia.

Rahayu Apriyanti Yofita. 2013. Menumbuhkan Kepercayaan Diri Melalui Kegiatan Bercerita. Jakarta. Index

Syaiful Bahri Djamarah dan Aswan Zain. (2006). Strategi Belajar Mengajar. Jakarta: Rineka Cipta

Sudjana. 2005. Metode Statistika. Bandung : Tarsiti Bandung.

Sugiono. 2013. Metode Penelitian Pendidikan. Pendekatan Kualitatif,Kuantitatif. Bandung: Alfabeta

Suhartono. (2005). Pengembangan Bicara Anak Usia Dini. Jakarta: Depdiknas.

TariganDjago. (2003). Pendidikan Bahasa Indonesia 1. Jakarta: Depdikbud.

Tarigan Henry G. (2013). Menyimak sebagai suatu Keterampilan Berbahasa. Bandung: Angkasa.

Yamin, Martinis. 2013. Strategi dan Metode Dalam Model Pembelajaran. Jakarta: Referensi.

Yuyun Nurfalah, dkk. 2007. Strategi Pembelajaran Kelompok Bermain Melalui Metode Mendongeng. Bandung Depdiknas Direktorat JendralPendodokan Luar Sekolah. 